\title{
DETERMINANTS OF CREDIT DECISION IN CONSUMER FINANCING: AN EMPIRICAL STUDY ON INDONESIA AUTO FINANCING
}

\author{
Suwinto Johan ${ }^{*}$ \\ *) Wiyatamandala School of Business \\ Cowell Tower Lt. 4, Jl. Senen Raya No.135, Senen, Kota Jakarta Pusat, Jakarta 10410
}

\begin{abstract}
The aim of the research was to study the impacts of retail consumer's $4 \mathrm{C}$ (character, capacity, collateral and capital) on the credit quality performance of finance company. The credit quality of the consumer was analyzed using a behavior scoring system. The dependent variable was the credit quality, i.e. the non performing financing of more-than-90-day-payment due. The independent variables were the characteristics, capacity, collateral, and capital of the debtors. The samples were customers who got financing from 2013-2014 and were cut off due to delinquency by the end of 2015. Total samples were 750 customers who purchased 4 wheelers. In this research, the econometrics model was regression binary logistic model. In the model, the dependent variable was the dummy variable of customers whose delinquency was under 90-day payment due and was given 0 , and the customers with delinquency more than 90-day payment due were given 1 . The empirical results showed that collateral and capital had significant influence on credit quality. The collateral was represented by the title of the car ownership (title of ownership). The capital was represented by the financing tenor, at significance level $=0.05$. The financing company should focus on the types of collateral, down payment, title of ownership and tenor of financing in determining credit decision.
\end{abstract}

Keywords: consumer, credit, finance company, lending, logistic

Abstrak: Tujuan dari penelitian ini adalah untuk mempelajari dampak 4 konsumen ritel C (karakter, kapasitas, agunan dan modal) pada kinerja kualitas kredit perusahaan pembiayaan. Kualitas kredit konsumen dianalisis menggunakan sistem penilaian perilaku. Variabel dependen adalah kualitas kredit, yaitu pembiayaan tidak berkinerja lebih dari 90 hari pembayaran. Variabel independen adalah karakteristik, kapasitas, agunan, dan modal debitur. Sampel adalah pelanggan yang mendapat pembiayaan dari 2013-2014 dan terputus karena kenakalan pada akhir tahun 2015. Jumlah sampel adalah 750 pelanggan yang membeli 4 roda. Dalam penelitian ini, model ekonometrika adalah regresi model logistik biner. Dalam model, variabel dependen adalah variabel dummy pelanggan yang kenakalannya di bawah pembayaran 90 hari jatuh tempo dan diberi 0 , dan pelanggan dengan kenakalan lebih dari pembayaran 90 hari yang diberikan 1. Hasil empiris menunjukkan bahwa jaminan dan modal memiliki pengaruh signifikan terhadap kualitas kredit. Jaminan diwakili oleh judul kepemilikan mobil (judul kepemilikan). Modal diwakili oleh tenor pembiayaan, pada tingkat signifikansi $=0,05$. Perusahaan pembiayaan harus fokus pada jenis agunan, uang muka, hak milik, dan jangka waktu pembiayaan dalam menentukan keputusan kredit.

Kata kunci: konsumen, kredit, perusahaan pembiayaan, pinjaman, logistik

${ }^{1}$ Corresponding author:

Email: suwintojohan@gmail.com 


\section{INTRODUCTION}

One of the main focuses of financial institution, particularly finance company, is to manage all types of risk. One of the crucial risks is credit risk. Credit risk is the main business risk in financing and lending. Credit risk represents the risk of the consumer's ability to pay back the principal and interest on the loan received or the credit received on time. Finance companies that are able to handle credit risk well will have good financial performance.

Credit risk begins with the selection of consumers to be given financing or credit. After the financing is given, the process of handling consumers becomes important. The higher the credit risk, the performance of financial institutions will become increasingly unfavorable.

The finance company will study the consumer behavior with non-performing loan as well as performing loan by using scoring and big data. The scoring will consist of the payment behavior, the demography, the social background and others. Artificial intelligence is used by giving score or value to every aspect of consumer which is considered to have an effect on credit quality and commitment of payment.

From this scoring system, the finance company will find the determinants of non-performing loan. These determinants is related with the foundation in giving credit which is $5 \mathrm{C}$ (Character, Conditions, Capacity, Collateral, and Capital). By using artificial intelligence, this scoring makes it easier for the finance company to conduct a credit assessment. Artificial intelligence (AI) will give a certain score or value on certain aspects to the consumer who will be given credits. The financing company will determine the limit of lending by granting categories approved, rejected and considered. The AI will also suggest the profile of customer to be approved. It will make it easier for the finance company and customer to determine the terms and conditions.

The use of credit scoring has increased the efficiency in credit and risk management of financial institutions. Credit scoring is implemented with several parametric methods (Blanco et al. 2013).

Credit scoring is developed to enhance the quality of banking credit and increase the objectivity and efficiency of credit decision making process. Credit quality determination is based on historical data of customer behavior that has occurred during the credit terms (Bee et al. 2011).

Devaney and Lytton (1995) found that the use of credit scoring enables the company to predict the rate of insolvency and risk of insolvency, and to pay debt of banking customers. This study investigated 5 variables, namely family status, employment status, personal information, financial data, and bureau credit information.

In the context of $5 \mathrm{C}$ concepts, namely Character, Conditions, Capacity, Collateral and Capital, each determinant is proxied with variables of the consumer. The Five $\mathrm{C}$ is described as follows: 1) Character is the nature of the potential consumer to be given credit; this factor becomes an important factor because it is used to know consumers' desire in fulfilling their obligations. 2) Capacity is the financial capability of the potential consumer in obtaining income and pay back on their obligations. 3) Capital is the amount of capital owned or inculcated by potential consumers; this capital is usually measured by the amount of down payment or the difference between the collateral and the loan value/liability. 4) Collateral refers to goods that will be guaranteed to the financing company; the financing company uses the collateral as a source of loan repayment, if the potential consumer is unable to repay the loan or under default. 5) Economic conditions are the external or macro factors that affect the conditions of potential consumers in returning their obligations; if the consumer does not meet the obligation to pay the installment due, then the finance company will face the non-performing loan (NPL).

If the non-performing loans increase, then the financial risk of the finance company will be disrupted. As a result, the financing company will experience liquidity problems that may lead to financial distress.

This research becomes unique because it analyzes the determinants of good quality credit in financing companies with a special portfolio of 4 wheeler-auto financing consumers during the 2013-2015 periods. There is no research that really focuses on special segments based on collateral. This research is limited only by examining the $4 \mathrm{C}$, excluding the conditions or macroeconomics parameters. 
Another uniqueness of the research that focuses on the $4 \mathrm{C}$ is that the conditions are the external factors of consumers and finance companies. Some similar studies were done by Kamaluddin (2015); Aryani (2016); and Ronny (2016).

Arif et al. (2016) conducted a study of 100 customers in PT. Bank Jateng and found that income, number of family, gender and job had a significant influence on individual credit at PT. PT. Bank Jateng. Meanwhile, the age of respondents did not have a significant influence on individual credit at PT. Bank Jateng. The study used linear regression.

Aryani (2016) examined the determinants of internal factors in banking and macroeconomic conditions which affected the Non-Performing Loan in sharia bank in Indonesia. This research included 7 sharia banks with data captured from 2010-2014. This study found that internal factors such as ROA, CAR, and Margin financing became the factors that influenced NPLs, and the external factors were GDP growth and exchange rates.

Ronny (2016) examined the analysis of the factors that influenced the credit quality in financing company PT XYZ Finance. In total the research used 15 parameters. This study found that characters, capacity, collateral and capital parameters influenced the credit quality of financing company PT XYZ Finance. Rokhim and Yanti (2014) conducted a research of NPLs in a regional development bank called Bank Perkreditan Rakyat. This study used panel data from the 2008-2011 periods. The study found that the program with $20 \%$ loan growth target and $40 \%$ productive loans increased the NPL.

Kamaluddin (2015) conducted a study to identify the determinants of Non-Performing Loan (NPL) in Indonesian banking sector. Data were collected from 16 banks by observations during the 2002-2011 periods. Further analysis was conducted by using Pooled EGLS (Cross-section random effects). The study found that NPLs were clearly driven by volatility and fluctuations in micro and macroeconomic factors. The factors consisted of loan to deposit ratio (LDR), capital adequacy ratio (CAR), net interest margin (NIM), inflation (INF), interest rate (IR), and exchange rate (ER), respectively, contributed to the variation of nonperforming loan (NPL) in Indonesia's banking sector.
Darusalam (2013) examined the factors causing the non-performing loan at PT Bank Sulut main branch of Manado. The result of the research was based on the extraction of analysis factor that obtained the most dominant factor i.e., the credit payment period, the determination of bank interest rate, and the amount of credit received.

Andriani et al. (2012) conducted a research on bank's customer credit payment fluency. This research used ordinal logistic regression model (case study: Bank Rakyat Indonesia Tbk. Bintuhan Market unit). According to the analysis and discussion result, it can be concluded that the positive factors that influence the lending are the gender of men, age, loans and collaterals, while the negative influence is the number of dependents in the family.

Limsombunchai et al. (2005) investigated the profitability of financial institutions that provided agricultural loan in Thailand. This study found the importance of loan to value of collateral, efficiency, and also the relationship between customers and banks. The higher the value of collateral, the more efficient the business activities of the customers were, and the better the credit quality was. Conversely, when the customer relationship with the bank was long, there was an inverse relationship to the credit quality.

This study examined the influence of $4 \mathrm{C}$ (Character, Conditions, Capital, and Capacity) on credit quality or non-performing loan risk in car financing in Indonesia. Non-performing loan was divided into 2 categories, namely 1) Consumers who had experienced delinquency in payments (delinquency or overdue) more than 90 days, and were categorized as problematic consumers; and 2) Consumers who had not experienced delinquency in payments (delinquency or overdue) less than 90 days, and categorized as normal customers in precautionary.

In total, there are 13 variables that are studied and grouped into 4 categories: 1) Character which consists of gender, age, length of stay, home ownership, marital status, and employment status; 2) Capacity which consists of income and cost ratio with income. 3) Collateral which consists of vehicle brand and vehicle ownership; and 4) Capital, which consists of down payment and tenor of financing. 


\section{METHODS}

The objects used in this research are the consumers of PT. XYZ during sales period of 2013 to 2014 dated as of June 31, 2015 with a product type of new used cars. With the sample size of 750 randomly selected customers, in this research, the obligation of consumer payment in a number of delinquent days becomes the dependent variable, while the independent variables are gender, marital status, work length, income, expenses, age, motor type, vehicle ownership, and tenor.

This research was conducted by using logistic regression model because the dependent variable model in this model was a dummy variable, by giving ' 0 ' value for the consumers who had the normal category, or ' 1 ', value for the precautionary that had delinquency above 90 days or above the substandard category. Logistic regression model is expressed as follows:

$$
\mathrm{Li}=\log \frac{P i}{1-P i}=b o+\sum_{j=1}^{k} \mathrm{~b}_{\mathrm{j}} \mathrm{X}_{\mathrm{ij}}
$$

Note: $\mathrm{Li}$ (Dependent variable $(=0$ for the quality of normal credit and precautionary credit and $=1$ for the category of credit quality "substandard", "doubtful", "loss")); Pi (Probability of credit quality); Xij (Independent variable).

From the model above, it is obtained for the credit quality prediction is as follows:

$$
\mathrm{Li}=\log \frac{P i}{1-P i}=b o+\mathrm{b}_{1} \mathrm{X}_{1}+\mathrm{b}_{2} \mathrm{X}_{2}+\ldots . .+\mathrm{b}_{13} \mathrm{X}_{13}+\mathrm{u}_{\mathrm{i}}
$$

Note: Li (Consumer Credit Quality); X1 (Gender); X2 (Marital Status); X3 (Length of Stay); X4 (House Ownership); X5 (Occupation); X6 (Length of work ); X7 (Income); X8 (Expense Ratio); X9 (Age); X10 (car brand); X11 (car ownership); X12 (Down payment); X13 (Tenor).

\section{Dependent Variable}

\section{Quality of Consumer Credit}

The quality of consumer credit is reviewed from the number of delinquent days after the due date of the installment payment obligation. If the period of delinquency is less than 90 days then the score is 0 , and if the period of delinquency is more than 90 days then the score is 1.

\section{Independent Variable}

\section{Character Parameters}

Gender; Gender is divided into two men i.e. men and women, which are; Women: Score 0; Men: Score 1; Marital Status; Marital status is categorized into two groups, namely Unmarried with the score 0 ; and Married with the score 1; Length of Stay; In this research, the length of stay is measured in the size of the year with the lowest value ' 1 ' and the highest value '6'; Home Status; In this research, home status is categorized into two, i.e., owned house with the score ' 0 ', and rented house with the score ' 1 '; Occupation; Non-self-employed occupation gets score ' 0 ', and self-employed (entrepreneurial) job gets score ' 1 '; Length of Work; Duration of work is used to measure the condition of the individual; how long the individual has worked in his/her field/ job, with the lowest score ' 1 ' and the highest score ' 6 '; Age; Age is the age of individual when making a credit agreement and using year as its unit.

2. Collateral Parameters (Productive age ranges between 15 years old and 60 years old).

Vehicle Brands; Non-Honda brand gets the score ' 0 ', and Honda brand gets the score ' 1 '; Vehicle Ownership; If the BPKB is under the consumer's name, it is given a score ' 0 ', and if not under the consumer's name, it is given a score ' 1 '.

3. Capital Parameters (Down Payment; Down Payment is used a percentage unit from $0 \%$ to100\%)

4. Capacity Parameters

Income; Income is used to measure the consumers' capacity, which is the individual ability to earn money from business/work; Tenor; Tenor or period of time is the length of time of the customer's payment until the proposed loan is paid. Definition of variables in Table 1 .

The research framework is illustrated in Figure 1. The 4C parameters are proxied to several variables tested for their influence on car financing credit quality. Hypothesis of the research in Table 2.

\section{RESULTS}

\section{Character Parameters}

From the total of 750 samples of consumers, most of the samples showed male has a mean of 0.66 (Table 3). For marital status, it indicates that over $83 \%$ samples have marital status. The samples have an average stay 
in a location over 1 year with an average stay of more than 5.5 years. Most consumer samples do not have a house yet - they only rent house or do not own a house -with a mean of 0.05 . The number of self-employed is higher than employee consumers. The self-employed consumer consists of $62 \%$ of the samples. The average consumers have worked for almost 5 years. The work experience could be as an employee, or an entrepreneur. The average age of consumers is between 41 years old and 21 years, and the oldest is at the age of 59 years.

\section{Capacity Parameters}

The average consumer income is 150,000,000 rupiah with the mean $\ln (15)$ in Table 3 . The lowest income is around 7,500,000 rupiah. The average cost compared to income is $34 \%$ and the highest $100 \%$.

\section{Collateral Parameters}

There are as many as $92 \%$ of consumers that are owners of Japanese brand car. The majority ownership of vehicles with customers/consumer financing is the same.

\section{Capital Parameters}

The average of down payment is $37 \%$. The highest is $85 \%$. The average of consumer tenor is 29 months - the longest is 36 months, and the shortest is 12 months. This study uses logistic regression to determine the partial influence of each independent variable on the dependent variable. Table 4 shows the test results using SPSS version 23.00. From Table 4, it can be seen the significance value of all variables below $0.05(<0.05)$, which represents that all variables influence the quality of consumer credit. Based on Table 4, the logistic regression model is as follows:

$\mathrm{Ln} \mathrm{p} /(1-\mathrm{p})=-12,287+0,310 \mathrm{JK}+0,117 \mathrm{SP}-0,126$ $\mathrm{LT}+17,729 \mathrm{SR}+0,438 \mathrm{JP}+0,167 \mathrm{LB}+0,373 \mathrm{P}-$ $0,186 \mathrm{ER}+0,018 \mathrm{U}-0,204 \mathrm{MM}+0,889 \mathrm{NB}-0,025$ $\mathrm{DP}+0,058 \mathrm{~T}$

*Note: JK: Gender, SP: Marital Status, LT: Length of Stay, SR: House ownership, NP: Occupation, LB: Length of work, P: Income, ER: Expense Ratio, U: Age, TM: Type car, NB: Car Ownership, DP: Down payment, $\mathrm{T}$ : Tenor.

Table 1. Definition of variables

\begin{tabular}{lll}
\hline Variable & Indicator & Scale \\
\hline Gender & $0=$ Women; 1 = Men & Nominal \\
Marital Status & $0=$ Not marries \& Widow/widower; 1 = Married & Nominal \\
Length of Stay & Years customers live in a place & Ratio \\
House Ownership Status & $0=$ Rental; 1 = Owned & Nominal \\
Occupation & $0=$ Non-self-employed; 1 = Self-employed & Nominal \\
Length of Work & Years the individual works in a business/office & Ratio \\
Income & Income in a month & Ratio \\
Expense Ratio & Ratio of Expenses compared to Income & Ratio \\
Age & Consumer's age & Ratio \\
Vehicle Brand & $0=$ Non-Japanese; 1 = Japanese & Nominal \\
Vehicle Ownership & $0=$ under consumer's name;1 = not under consumer's name & Nominal \\
Down Payment & Down Payment & Ratio \\
Tenor & Period of Financing/Credit & Ratio \\
Credit Quality & $0=<90$ day of delinquency; 1 = $>90$ day of delinquency & Nominal \\
\hline
\end{tabular}

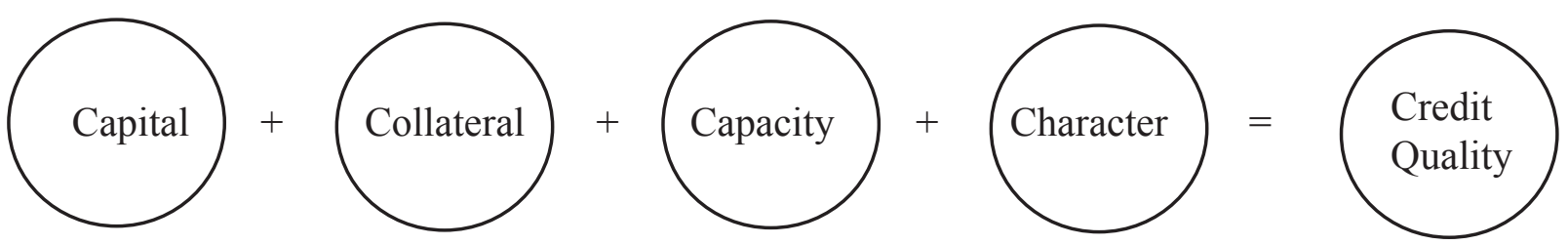

Figure 1. Concept of credit quality 
Table 2. Hypothesis

\begin{tabular}{ll}
\hline \multicolumn{1}{c}{ Hypothesis of the research } & \multicolumn{1}{c}{ Previous research } \\
\hline H01: Character has no influence on credit quality & $\begin{array}{l}\text { Devaney \& Lytton (1995), Andriani et al. (2012) Arif et al. } \\
(2016), \text { Ronny (2016) }\end{array}$ \\
H02: Capacity has no influence on credit quality & Ronny (2016) \\
H03: Collateral has no influence on credit quality & $\begin{array}{l}\text { Limsombunchai et al. (2005), Andriani et al. (2012), } \\
\text { Ronny (2016) }\end{array}$ \\
H04: Capital has no influence on credit quality & $\begin{array}{l}\text { Limsombunchai et al. (2005), Darusalam (2013), Ronny } \\
(2016)\end{array}$ \\
\hline
\end{tabular}

Table 3. Statistic description

\begin{tabular}{lccccc}
\hline & $\mathrm{N}$ & Minimum & Maximum & Mean & Std. Deviation \\
\hline Gender & 750 & 0.00 & 1.00 & 0.66 & 0.47 \\
Marital Status & 750 & 0.00 & 1.00 & 0.83 & 0.38 \\
Length of Stay & 750 & 1.00 & 6.00 & 5.63 & 0.99 \\
House Ownership & 750 & 0.00 & 1.00 & 0.05 & 0.22 \\
Job Status & 750 & 0.00 & 1.00 & 0.62 & 0.49 \\
Length of Work & 750 & 1.00 & 6.00 & 5.44 & 1.17 \\
Income & 750 & 15.45 & 20.21 & 16.95 & 0.73 \\
Expense Ratio & 750 & 0.00 & 10.00 & 0.34 & 0.15 \\
Age & 750 & 21.00 & 59.00 & 40.48 & 8.51 \\
Collateral Brand & 750 & 0.00 & 1.00 & 0.92 & 0.28 \\
Ownership & 750 & 0.00 & 1.00 & 0.60 & 0.49 \\
Down payment & 750 & 24.00 & 85.00 & 37.24 & 12.74 \\
Tenor & 750 & 12.00 & 36.00 & 29.23 & 8.73 \\
Credit Quality & 750 & 0.00 & 1.00 & 0.04 & 0.21 \\
Valid N & 750 & & & & \\
\hline
\end{tabular}

Table 3. Statistic description

\begin{tabular}{lcc}
\hline Variable & $\mathrm{B}$ & Sig. \\
\hline Gender & 0.310 & 0.45 \\
Marital Status & 0.117 & 0.84 \\
Length of Stay & -0.126 & 0.51 \\
House ownership & -17.728 & 1.00 \\
Occupation & 0.438 & 0.32 \\
Length of work & 0.167 & 0.42 \\
Income (ln) & 0.373 & 0.13 \\
Expense Ratio & -0.186 & 0.87 \\
Age & 0.018 & 0.42 \\
Vehicle Brand & -0.204 & 0.76 \\
Vehicle Ownership & 0.889 & 0.05 \\
Down Payment & -0.025 & 0.27 \\
Tenor & 0.058 & 0.04 \\
Constant & -12.287 & 0.01 \\
\hline
\end{tabular}

Test Result on H1 (Character)

For character parameters, 7 variables tested showed that there is no significant influence on credit quality. Gender, age, marital status, occupation and working experience have no influence on credit quality. Hence, it can be concluded that consumers who purchase a used car has a strong commitment to fulfill their obligations to finance company. The result supports the research done by Andriani et al. (2012), Arif (2016), and Ronny (2016).

Test Result on H2 (Capacity)

Income variables showed there is no influence on credit quality. Expense ratio also showed no impact on credit quality. It could be concluded that the consumer has higher income and higher commitment to their obligations. The result is also in line with the research done by Ronny (2016). 
Collateral variable indicates that collateral must have the same data between customers of financing company with data of collateral, such as the name recorded at BPKB (Proof of Owner of Motorized Vehicle). Normally, it will take a few months for consumer to change the title from the stated owner to their name. It will also cost the consumer up to $10 \%$ of the financing amount. However, the title changed will represent their willingness or their character. In addition, Japanese car have no significance in credit quality compared to other non-Japanese brands. It could be summarized that $92 \%$ of the total portfolio is Japanese brand car. The result research is also supported by Andriani et al. (2012, Limsombunchai et al. (2005), and Ronny (2016).

\section{Test Result on H4 (Capital)}

Down payment and tenor variables have the opposite characteristics. The shorter the tenor, the lower the credit risk is. Tenor showed a significant influence on credit quality. Tenor represents the income and expense ratio of the consumer. The shorter the tenor, the higher the capacity to repay the loan is. Down payment showed no influence on credit quality. Normally, the higher the down payment, the smaller the credit risk is. The consumers who pay a down payment will keep the credit quality and pay the installment on time compared with consumers with a small down payment. Hence, it can be concluded that a short tenor will have a better credit quality. The research result is supported by the research done by Limsombunchai et al. (2005), Darusalam (2013), and Ronny (2016).

\section{Managerial Implication}

Based on the research, the risk management of financing company should focus on the collateral ownership and tenor of financing in credit decision. The credit management should put more effort on verification of collateral ownership. The collateral ownership could be verified by getting clearance from local authority. Tenor is one of the important variables to be considered on the financing. Based on the research, the longer financing period the higher risk will be. However, the longer financing tenor will provide the higher income to the financing company. A balance should be applied on the business decision.

\section{Conclusions}

From the study, it can be concluded that character has no influenceon theconsumers'creditquality for thepurchase of four-wheeler, especially gender, marital status, age, occupation type, length of employment, ownership of house, and length of stay variables. Capacity has no influence on the credit quality, especially for income and expense ratio variables. Collateral influences the credit quality on proof of ownership/title of the vehicle variable. Capital also influences the credit quality, especially on tenor variable. The result of this study has completed the research done by Limsombunchai et al. (2005), Andriani et al. (2012), Darusalam (2013), Ronny (2016), and Arif (2016). The results will assist financing company in determining credit decision efficiently. Further research could be done in other types of collateral, such as heavy equipment, 2 wheelers and other business segments.

\section{Recommendations}

We propose to add other variables on future research, such as the credit records of the customers, type of business, education background and other demography variables. We also propose to use other models of consumer credit such as mortgage, credit card and personal loans.

\section{REFERENCES}

Andriani YMU, Hanum H. 2012. Model Tingkat Kelancaran Pembayaran Kredit Bank Menggunakan Model Regresi Logistik Ordinal (Studi Kasus: Bank Rakyat Indonesia Tbk Unit Pasar Bintuhan). Jurnal Gradien 8(2):809-814

Arif H, Muliawan S, Hamdani. 2016. Determinan Kredit Perorangan (Personal Loan) (Studi Kasus pada Nasabah Personal Loan PT. Bank Jateng) Media Ekonomi dan Manajemen 31 (1) Januari 2016

Aryani Y. 2016. Bank Specific and Macroeconomic Determinants of Non Performing Financing in Islamic Banking Indonesia [tesis]. Bogor: Sekolah Pascasarjana Institut Pertanian Bogor

Bee WP, Ismail NH, Simon F. 2011. Predicting car purchase intent using data mining approach. 2011 Eighth International Conference on Fuzzy 
Systems and Knowledge Discovery (FSKD).

Blanco A, Pino-Mejías R, Lara J, Rayo S. 2013. Credit scoring models for the microfinance indus- try using neural networks: Evidence from Peru. Expert Systems with Applications 40: 356-364.

Darusalam O. 2013. Faktor-faktor penyebab kredit bermasalah di PT. BANK SULUT cabang utama Manado. Jurnal EMBA 1(4): 69-7.

DeVaney SA, Lytton RH. 1995. Household insolvency: A review of household debt repayment, delinquency, and bankruptcy. Financial Services Review 4(2): 137-156. https://doi. org/10.1016/1057-0810(95)90008-X.

Kamaludin D, Usman B. 2015 Determinan non performing loan (NPL) pada industri perbankan (bukti empiris perusahaan go publik di bursa efek indonesia). Jurnal Aplikasi Manajemen 13(4):547-556.

Limsombunchai V, Gan C, Lee, M. 2005. An analysis of credit scoring for agricultural loans in Thailand. American Journal of Applied Science 2(8): 1198-1205. https://doi.org/10.3844/ ajassp.2005.1198.1205.

Rokhim R, Yanti MISM. 2014. Risiko NPL Kredit Bank Pembangunan Daerah sebagai Regional Champion. Jurnal Keuangan dan Perbankan 18(1): 120-129.

Ronny F. 2016. Analisis Faktor-faktor yang mempengaruhi kualitas kredit pada perusahaan pembiayaan PT. XYZ Finance [tesis]. Jakarta: Program Pascasarjana Magister Manajemen, Universitas Tarumanagara. 